Article

\title{
Harvesting Scenedesmus obliquus via Flocculation of Moringa oleifera Seed Extract from Urban Wastewater: Proposal for the Integrated Use of Oil and Flocculant
}

\author{
Alejandro Ruiz-Marin ${ }^{1, *(1)}$, Yunuen Canedo-Lopez ${ }^{1}$, Asteria Narvaez-Garcia ${ }^{1}$,

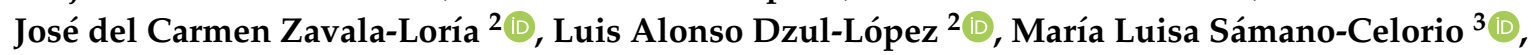 \\ Jorge Crespo-Álvarez ${ }^{4}$ (D), Eduardo García-Villena ${ }^{4}$ and Pablo Agudo-Toyos ${ }^{4}$ (D) \\ 1 Facultad de Química, Universidad Autónoma del Carmen, Campeche C.P. 24180, Mexico; \\ ycanedo@pampano.unacar.mx (Y.C.-L.); anarvaez@pampano.unacar.mx (A.N.-G.) \\ 2 Project Department, Universidad Internacional Iberoamericana, Campeche C.P. 24560, Mexico; \\ jose.zavala@unini.edu.mx (J.d.C.Z.-L.); luis.dzul@unini.edu.mx (L.A.D.-L.) \\ 3 Centro de Investigación y Tecnología Industrial de Cantabria (CITICAN), 39011 Santander, Spain; \\ marialuisa.samano@citican.org \\ 4 Polytechnic School, Universidad Europea del Atlántico, 39011 Santander, Spain; \\ jorge.crespo@funiber.org (J.C.-Á.); egarcia@funiber.org (E.G.-V.); pablo.agudo@uneatlantico.es (P.A.-T.) \\ * Correspondence: aruiz@pampano.unacar.mx; Tel.: +52-93-838-110-18 (ext. 2103)
}

Received: 27 August 2019; Accepted: 14 October 2019; Published: 21 October 2019

\begin{abstract}
The objectives this study were to examine the integrated use of oil-coagulant for the direct extraction of coagulant from Moringa oleifera (MO) with $5 \%$ and $10 \%\left(\mathrm{NH}_{4}\right)_{2} \mathrm{SO}_{4}$ extractor solution to harvest Scenedesmus obliquus cultivated in urban wastewater and to analyze the oil extracted from MO and S. obliquus. An average content of $0.47 \mathrm{~g}$ of coagulant and $0.5 \mathrm{~g}$ of oil per gram of MO was obtained. Highly efficient algal harvest, $80.33 \%$ and $72.13 \%$, was achieved at a dose of $0.38 \mathrm{~g} \mathrm{~L}^{-1}$ and $\mathrm{pH} 8-9$ for $5 \%$ and $10 \%$ extractor solutions, respectively. For values above $\mathrm{pH} 9$, the harvest efficiency decreases, producing a whitish water with $10 \%\left(\mathrm{NH}_{4}\right)_{2} \mathrm{SO}_{4}$ solution. The oil profile (MO and S. obliquus) showed contents of SFA of 36.24-36.54\%, monounsaturated fatty acids of $32.78-36.13 \%$, and polyunsaturated fatty acids of $27.63-30.67 \%$. The biodiesel obtained by S. obliquus and $\mathrm{MO}$ has poor cold flow properties, indicating possible applications limited to warm climates. For both biodiesels, good fuel ignition was observed according to the high cetane number and positive correlation with SFA and negative correlation with the degree of saturation. This supports the use of $\mathrm{MO}$ as a potentially harmless bioflocculant for microalgal harvest in wastewater, contributing to its treatment, and a possible source of low-cost biodiesel.
\end{abstract}

Keywords: coagulation-flocculation; harvest microalgal; Moringa oleifera; Scenedesmus obliquus; biodiesel quality

\section{Introduction}

Bodies of water are constantly exposed to various concentrations of pathogenic bacteria, nutrients, organic matter, and heavy metals, occasionally reaching dangerous levels [1,2]. Conventional methods for wastewater treatment are expensive and sometimes inefficient depending on the technology used and their type of maintenance. Wastewater is usually discharged into natural receiving bodies of water but does not contaminate ecosystems or threathen human health with proper treatment. Although various technologies are available for the treatment of wastewater, the use of photosynthetic microorganisms has received attention as an alternative for the removal of nutrients; for this reason, researchers have concluded that the cultivation of microalgae in wastewater provides dual benefits: 
the efficient removal of nutrients and the production of algal biomass that can be used as raw material for the extraction of high value chemicals and biofuel synthesis (bioethanol and biodiesel).

One of the major practical limitations of wastewater treatment using photosynthetic microorganisms is harvesting the algal biomass from the treated effluent. Some methods, such as centrifugation, flocculation, chemical coagulation, electrolytic process, gravity sedimentation, filtration and screening, flotation, dissolved air flotation, dispersed air flotation, electrophoresis techniques, and immobilized cells, are expensive given the maintenance and energy requirements [3-6], through which harvesting could only be justified in cases where high-cost products are fabricated, such as drug precursors and materials for pharmaceutical purposes [7]. This means that operating costs should be decreased drastically to ensure that production and commercialization become feasible.

Physicochemical processes are widely adopted to treat wastewater effluents, including membrane filtration, ion exchange, advanced oxidation, adsorption, and coagulation-flocculation [8-10]. Coagulation-flocculation is particularly attractive among the processes due to its low cost, simple operation, high efficiency biomass recovery, and improvement of the effluent's quality [11]. Selecting the coagulant influences the recovery efficiency of algal biomass; the coagulent's use should not contaminate and affect the biomass's quality, since this would incur additional costs for the biomass's purification. The synthesis of coagulants includes inorganic and organic coagulants, which are widely used for the treatment of wastewater. However, studies suggest that some of these coagulants have negative effects, such as the aluminum coagulant causing Alzheimer's disease and the acrylamide monomer in polyacrylamide also being neurotoxic to humans [12-14]. Therefore, the demand is increasing for the use of coagulants with higher efficiency that are safe for both the environment and human health.

Natural coagulants extracted from plants such as Moringa oleifera seed, Jatropha curcas, copra, and cactus have shown promise as abundant raw materials for obtaining biodegradable organic coagulants with low toxicity [15]. As a coagulant, M. oleifera seeds have been recognized as one of the best natural products for wastewater treatment. Studies have reported that the seeds can be used to remove pollutants including turbidity, heavy metals, Escherichia coli bacteria, algae, and water surfactants $[2,6,10]$, which is attributed to the cationic protein contained in M. oleifera seeds as an active bio-coagulating component for the treatment of wastewater. The seeds have potential as bioflocculants in the microalgae biomass separation process and harvesting [16]. The objective of this study was to explore the potential of the oil and biocoagulant-flocculant of $M$. oleifera seed in microalgae cultures in wastewater and to evaluate the possible effects of flocculant contamination on the biodiesel quality obtained from the synthesis of algal fatty acids.

\section{Materials and Methods}

\subsection{Seed Preparation Moringa Oleifera (MO)}

The MO seeds were obtained from trees that grow in the region of Ciudad del Carmen, Campeche, Mexico. The dried pods were collected and cleaned manually, leaving the seeds free from rind. The MO seeds were dried in an oven at $60{ }^{\circ} \mathrm{C}$ for $24 \mathrm{~h}$ and then ground and sieved in a stainless steel sieve $(600 \mu \mathrm{m})$ until a homogeneous fine powder was produced. For conservation, MO powder was stored in moisture- and light-free containers to prevent oxidation and the degradation of its active properties.

\subsection{Oil Extraction}

The oil extraction was performed according to Sato and Murata [17] and Canedo-Lopez et al. [18]. Six samples in a triplicate of different quantities $\left(\mathrm{P}_{1}\right)$ of $\mathrm{MO}$ powder $(1,2,4,6,8$, and $10 \mathrm{~g})$ were used for the oil extraction. For each sample, $50 \mathrm{~mL}$ of chloroform-methanol solution $(2: 1 \mathrm{v} / \mathrm{v})$ was added, then the $\mathrm{MO}$ and solvent mixture was placed in ultrasonic equipment $(70 \mathrm{~Hz})$ for $1 \mathrm{~h}$ at $4{ }^{\circ} \mathrm{C}$. The samples were centrifuged (4500 rpm, $25 \mathrm{~min}$ ) and the solvent-oil supernatant was evaporated to concentrate the oil for subsequent transesterification prior to the identification of lipids. The oil-free MO extract 
was oven-dried $\left(60{ }^{\circ} \mathrm{C}\right)$ up to a constant weight $\left(\mathrm{P}_{2}\right)$ for $24 \mathrm{~h}$. The weight difference between $\mathrm{P}_{1}$ and $\mathrm{P}_{2}$ represents the extracted oil content $(\mathrm{g})$.

\subsection{Removal of One-Step Flocculant}

To obtain an inexpensive coagulant and for practical purposes, a simple one-step extraction methodology was used as it is feasible to use on larger scales, where the coagulant-flocculant efficiency could be conserved in microalgae cultures in wastewater. The procedure consisted in extracting coagulant protein from the oil-free MO extract. For the MO sample, a $50 \mathrm{~mL}$ of $5 \%$ and $10 \%\left(\mathrm{NH}_{4}\right)_{2} \mathrm{SO}_{4}$ solution was added. The samples were placed in ultrasonic equipment $(70 \mathrm{~Hz})$ for 15 min at $4{ }^{\circ} \mathrm{C}$, and let to stand for $24 \mathrm{~h}$ in refrigeration and darkness. After this time, the samples were centrifuged (4500 rpm) for $15 \mathrm{~min}$ and the supernatant containing the coagulant was separated and kept under refrigeration in the dark for subsequent coagulation-flocculation efficiency tests using the jar test equipment in Scenedesmus obliquus cultures from urban wastewater and urban wastewater only. The extraction of coagulant-free $\mathrm{MO}$ was dried in an oven $\left(60^{\circ} \mathrm{C}\right)$ up to a constant weight $\left(\mathrm{P}_{3}\right)$ for $24 \mathrm{~h}$, with the difference in weight between $\mathrm{P}_{2}$ and $\mathrm{P}_{3}$ was used to determine the content of coagulant $(\mathrm{g})$.

\subsection{Cultivation of the Microalga Scenedesmus Obliquus}

S. obliquus microalga was selected for its ability to grow in urban wastewater and efficiently remove nitrogen and phosphorus. The composition of the equivalent culture medium (CME) for the acclimatization of $S$. obliquus was designed according to the main characteristics of a primary treatment effluent [4], with the addition of trace metals and vitamins similar for f/2 medium [19]. The culture conditions for an initial cellular density of $2 \times 10^{6}$ cells $\mathrm{mL}^{-1}$ were $28 \pm 1^{\circ} \mathrm{C}$ at a light intensity of $100 \mu \mathrm{E} \mathrm{m}^{-2} \mathrm{~s}^{-1}$ using light-white fluorescent lamps and $0.4 \mathrm{~L} \mathrm{~L}^{-1} \mathrm{~min}^{-1}$ aeration. For the analysis of coagulation-flocculation efficiency, the S. obliquus microalgae was cultivated in six cylindrical bioreactors composed of $2 \mathrm{~L}$ transparent polyethylene terephthalate (PETE) containing CME in triplicate, pre-washed with a chlorine solution $(0.5 \%)$ to prevent bacterial contamination. The two-stage method was used to increase the accumulation of lipids in all cultures. The procedure consisted of installing reactors of culture with an initial volume of $1 \mathrm{~L}$ with half residual water enriched with nitrogen (90 $\mathrm{mg} \mathrm{N}-\mathrm{NH}_{4} \mathrm{~L}^{-1}$ ), with the cultures diluted at the end of the exponential phase by adding fresh medium (1 L) until a concentration of $10 \mathrm{mg} \mathrm{N}-\mathrm{NH}_{4} \mathrm{~L}^{-1}$ was reached.

For the analysis of the coagulation efficiency in a domestic effluent, samples were collected from the discharge of aerobic treatment plants (Table 1). The samples were homogenized to obtain a representative sample of urban wastewater from the treatment plants in the municipality of the Ciudad del Carmen, Campeche; Mexico.

\subsection{Experimental Design: Jar Test}

A standard jar test was used to explore the coagulation-flocculation efficiency. A series of six $1.5 \mathrm{~L}$ reactors were installed containing cultures of $S$. obliquus in urban wastewater and another series with only urban wastewater. To determine the optimal dose, the flocculant extracted from the MO was added in each of the reactors and mixed rapidly $(120 \mathrm{rpm})$ for $30 \mathrm{~s}$, followed by a lens mixture (40 rpm) for $30 \mathrm{~min}[10,20]$. The mixture was allowed to settle for $1 \mathrm{~h}$ and water samples were collected to determine turbidity. The sediment microalgae were collected and centrifuged (4000 rpm for $15 \mathrm{~min}$ ), eliminating the largest amount of water for subsequent lyophilization and lipid extraction. The percentage of removal $(R)$ for both treatments was calculated with the following equation:

$$
R=\frac{C o-C f}{C_{0}} * 100
$$

where $C_{o}$ and $C_{f}$ are the initial and final turbidity, respectively. 
Table 1. Chemical parameters determined for wastewater effluent of treatment plants (WPT). The results represent average values (samples in triplicate) and standard deviation ( $\pm \mathrm{SD})$.

\begin{tabular}{lcccc}
\hline \multicolumn{1}{c}{ Parameter } & Units & \multicolumn{3}{c}{ Effluent Characteristics } \\
\hline Temperature & & WPT $_{\mathbf{1}}$ & WPT $_{\mathbf{2}}$ & WPT $_{\mathbf{3}}$ \\
$\mathrm{pH}$ & ${ }^{\circ} \mathrm{C}$ & $26.3 \pm 0.2$ & $27.0 \pm 0.1$ & $27.6 \pm 0.01$ \\
Total phosphorus & $\mathrm{mg} \mathrm{L}^{-1}$ & $19.64 \pm 0.1$ & 7.47 & 7.10 \\
Total nitrogen & $\mathrm{mg} \mathrm{L}^{-1}$ & $99.13 \pm 0.02$ & $18.64 \pm 0.1$ & $3.10 \pm 0.1$ \\
$\mathrm{~N}-\mathrm{NH}_{4}$ & $\mathrm{mg} \mathrm{L}^{-1}$ & $90.75 \pm 0.03$ & $17.06 \pm 0.02$ & $2.84 \pm 0.02$ \\
$\mathrm{~N}-\mathrm{NO}_{3}$ & $\mathrm{mg} \mathrm{L}^{-1}$ & $8.29 \pm 0.01$ & $1.81 \pm 0.01$ & $0.32 \pm 0.03$ \\
$\mathrm{~N}-\mathrm{NO}_{2}$ & $\mathrm{mg} \mathrm{L}^{-1}$ & $0.08 \pm 0.1$ & $0.013 \pm 0.2$ & $0.002 \pm 0.2$ \\
Rate N/P & & 5.04 & 4.97 & 0.73 \\
Fats and oil & $\mathrm{mg} \mathrm{L}^{-1}$ & $20.26 \pm 1.2$ & $8.03 \pm 2.2$ & $10.75 \pm 1.8$ \\
BOD & $\mathrm{mg} \mathrm{L}^{-1}$ & $212 \pm 0.8$ & $28 \pm 1.2$ & $43 \pm 0.5$ \\
SST & $\mathrm{mg} \mathrm{L}^{-1}$ & $117 \pm 0.5$ & $27 \pm 0.2$ & $40 \pm 0.3$ \\
Turbidity & $\mathrm{NTU}$ & 981 & 830 & 633 \\
\hline
\end{tabular}

Note: BOD: Biochemical Oxygen Demand; SST: Total Suspended Solids; NTU: Nephelometric Turbidity Units.

\subsection{Fatty Acid Methyl Esters (FAME) Profile}

The biomass recovered from the jar test was frozen at $-4.0^{\circ} \mathrm{C}$ for $48 \mathrm{~h}$, and then lyophilized for 3 days; the resulting dry biomass was stored at $0{ }^{\circ} \mathrm{C}$. Total lipids were extracted following the dry extraction procedure described by Canedo-Lopez et al. [18]. The transesterification of fatty acids for the algal biomass and MO were according to the methods reported by Sato and Murata [17]. The FAME profiles were determined using a gas chromatographer (GC) (Agilent Technology 7890, CA, USA). One microliter of the FAME-hexane solution was injected into the GC equipped with a flame ionization detector (FID) and DB-23 column (60 m length, $0.32 \mathrm{~mm}$ internal diameter, $0.25 \mu \mathrm{m}$ thick); helium was the carrier gas. The injector and detector temperature was $250{ }^{\circ} \mathrm{C}$. The temperature program was: $120^{\circ} \mathrm{C}$ for $5 \mathrm{~min} ; 10^{\circ} \mathrm{C} \mathrm{min}-1$ increases until reaching $180^{\circ} \mathrm{C}$ for $30 \mathrm{~min} ; 10^{\circ} \mathrm{C} \mathrm{min}{ }^{-1}$ increases until reaching $210^{\circ} \mathrm{C}$ for $21 \mathrm{~min}$. A calibration curve was prepared for all FAMEs by injecting known concentrations of an external standard mixture containing 37 FAMEs (Supelco, Bellefonte, PA, USA); the correlation coefficient was equal to or greater than $95 \%$ in all cases.

\subsection{Biodiesel Fuel Property Estimates}

The biodiesel quality parameters obtained from S. obliquus and MO were estimated as described by Vidyashankar et al. [21] and Guldhe et al. [22].

The saponification value (SV), cetane number (CN), iodine value (IV), long chain saturated factor (LCSF), and cold filter plugging point (CFPP) were estimated for the fatty acid composition of the microalgae and MO as described by Vidyashankar et al. [21] and Guldhe et al. [22]:

$$
\begin{gathered}
S V=\sum \frac{560 N}{M}, \\
I V=\sum \frac{254 D N}{M}, \\
C N=46.3+\frac{5458}{S V}-0.225 I V, \\
L C S P=[0.1 C 16(w t \%)+0.5 C 18(w t \%+1 . C 20(w \mathrm{t} \%)+1.5 C 22(\mathrm{wt} \%)+2 . C 24(\mathrm{wt} \%)], \\
C F P P=(3.1417 * L C S F)-16.477,
\end{gathered}
$$


where $S V, C N, I V, L C S F$, and $C F P P$ are the saponification value, cetane number, iodine value, long chain saturated factor and cold filter plugging point, respectively; and $D, M$, and $N$ denote the number of double bonds, molecular mass, and percent mass fraction of each fatty acid component, respectively.

$$
\begin{gathered}
\qquad \mathrm{DU}=\text { MUFA }+(2 * \text { PUFA }) \\
\text { Oxidative stability }(\mathrm{OS})=-(0.0384 * D U)+7.77
\end{gathered}
$$

where $D U$ is the amount of unsaturated fatty acid (MUFA) and polyunsaturated fatty acid (PUFA), calculated from the fatty acid profile [22,23]. The properties of synthesized biodiesel were compared with the specifications provided by ASTM 6751 and EN14214 standards.

\subsection{Statistical Analysis}

An analysis of variance (ANOVA, $P \leq 0.05$ ) was applied to evaluate the optimum dose and $\mathrm{pH}$ in the coagulation-flocculation potential of the M. oleifera seed on S. obliquus cultures in urban wastewater. The effect of the coagulant in the fatty acid profiles of the algal biomass harvested and synthesis of biodiesel was also evaluated. Tukey's test of honestly significant difference (HSD) was applied when results exhibited significant differences.

\section{Results and Discussion}

Our study of the integrated use of MO seed included an analysis of the potential of extracted oil and bioflocculating-coagulating activity (Figure 1). The results showed a positive correlation (correlation coefficient $(R)=0.94$ ) between the oil content and the amount of MO (Figure 2) suggesting that for each gram of the M. oleifera seed, approximately $0.5 \mathrm{~g}$ oil can be obtained $(50 \%, w / w)$ (Equation (8)).

With this method, MO shows potential as a raw material source of low-cost energy according to the content and characteristics of the oil, with the additional advantage of having potential as a bioflocculant for the recovery of algal biomass in cultures with urban wastewater, contributing to the treatment of sewage water.

$$
\begin{gathered}
\text { Oil }(\mathrm{g})=0.4013(\mathrm{MO})+0.2141 \\
\text { Coagulant }(\mathrm{g})=0.2583(\mathrm{MO})+0.2099
\end{gathered}
$$

Although no significant differences were observed $(P=0.345)$ in the content of the coagulant extracted under the two concentrations (5\% and $10 \%$ ) of extracting solution $\left(\mathrm{NH}_{4}\right)_{2} \mathrm{SO}_{4}$, all the extractions were used in the jar tests with the purpose of identifying the optimal dose and $\mathrm{pH}$ (Table 2), as well as the possible contaminant effect of the coagulant on the quality of the oil extracted from the algal biomass. The average content of coagulant extracted for the six samples showed a positive correlation $(R=0.94)$ with respect to the MO content $(\mathrm{g})$; suggesting that approximately $0.47 \mathrm{~g}$ of coagulant could be obtained per gram of $\mathrm{MO}(w / w$; Equation (9)). The linearity shows an interception with the waste generated, suggesting that the extraction capacity of the extracting solution $\left(\mathrm{NH}_{4}\right)_{2} \mathrm{SO}_{4}$ tends to decrease as the raw material of $\mathrm{MO}$ increases, meaning that a part of the $\mathrm{MO}$ could still coagulated without reacting with the solution $\left(\mathrm{NH}_{4}\right)_{2} \mathrm{SO}_{4}$, producing higher excess residue. Therefore, under the operating conditions presented in this study, $4 \mathrm{~g}$ of $\mathrm{MO}$ and a volume of $50 \mathrm{~mL}$ of $5 \%$ or $10 \%$ $\left(\mathrm{NH}_{4}\right)_{2} \mathrm{SO}_{4}$ could satisfactorily extract coagulant (Figure 2). 

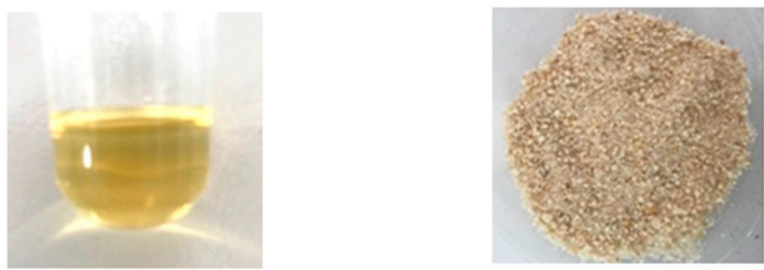

(a)

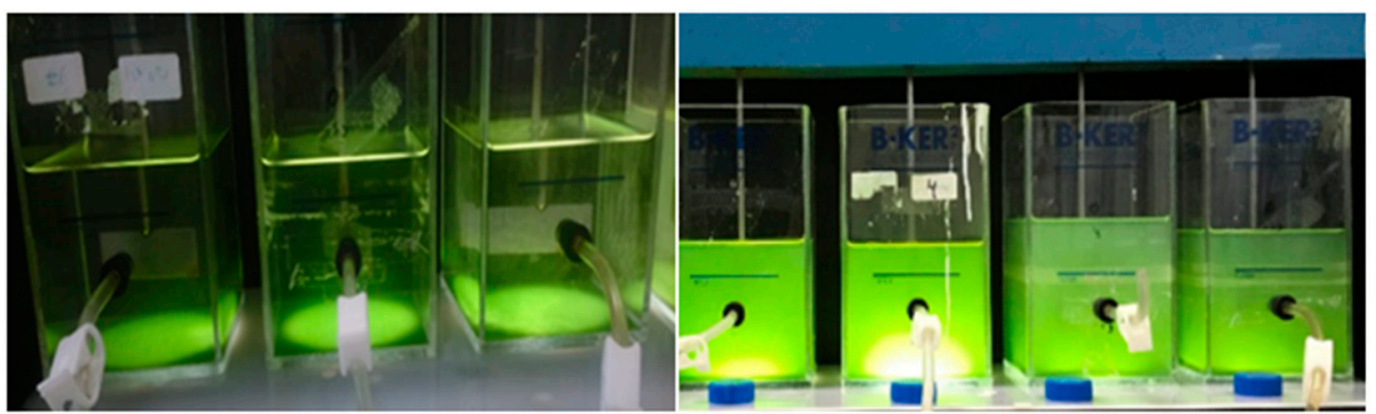

(b)

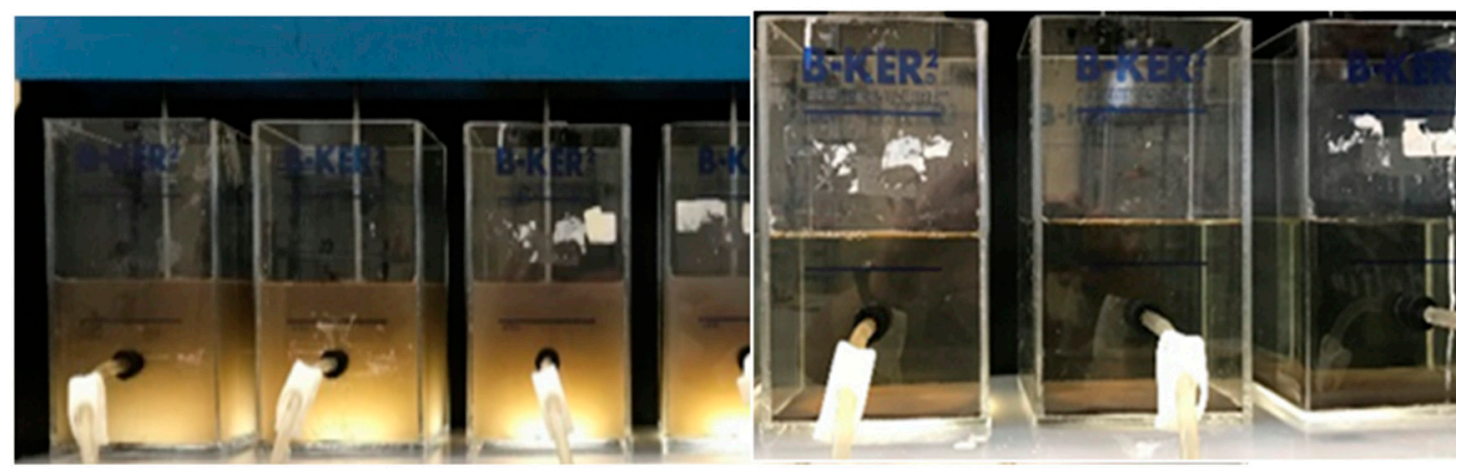

(c)

Figure 1. Jar test, dose determination, and optimal $\mathrm{pH}$ during the algal flocculation with urban wastewater: (a) Oil extraction from Moringa oleifera seed; (b) flocculation with microalgae culture; and (c) flocculation with urban wastewater.

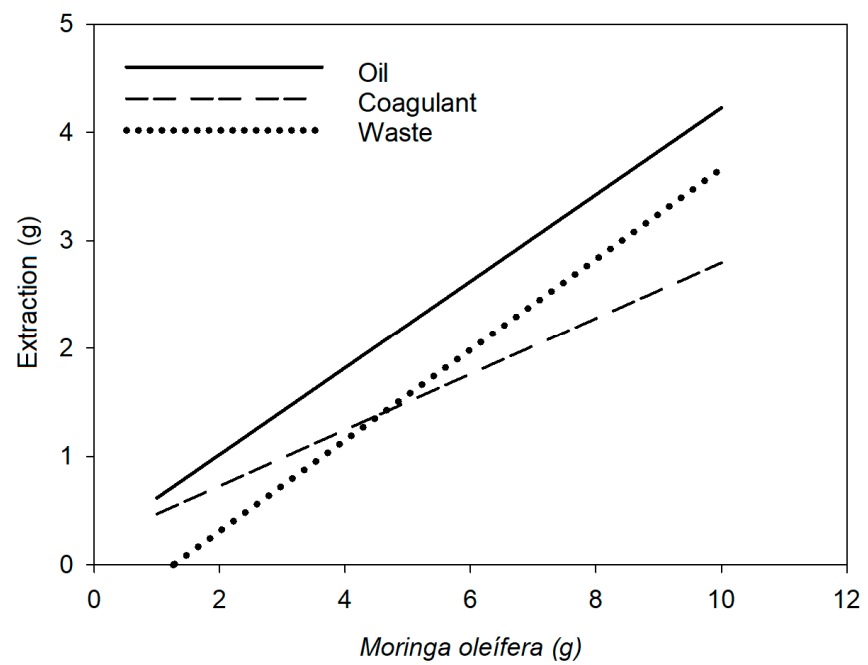

Figure 2. Linearity of the oil content (g) and biomass of Moringa oleifera. 
Table 2. Flocculant content extracted from Moringa oleifera $(\mathrm{g})$ per volume of extracted solution $(\mathrm{mL})$.

\begin{tabular}{cccc}
\hline Moringa oleifera $(\mathbf{g})$ & \multicolumn{2}{c}{$\frac{\mathbf{g} \text { flocculant }}{\mathbf{m L}\left(\mathbf{N H}_{4} \mathbf{~}_{2} \mathbf{S O}_{4}\right.}$} \\
\hline & \multicolumn{2}{c}{ Solution $\left(\mathbf{N H}_{4}\right)_{\mathbf{2}} \mathbf{S O}_{\mathbf{4}}$} \\
\hline & $\mathbf{5 \%}$ & $\mathbf{1 0 \%}$ & Average \\
\hline 1 & $0.009 \pm 0.001^{\mathrm{a}}$ & $0.007 \pm 0.001^{\mathrm{a}}$ & 0.008 \\
2 & $0.016 \pm 0.002^{\mathrm{a}}$ & $0.015 \pm 0.001^{\mathrm{a}}$ & 0.015 \\
4 & $0.029 \pm 0.003^{\mathrm{a}}$ & $0.019 \pm 0.007^{\mathrm{a}}$ & 0.024 \\
6 & $0.036 \pm 0.008^{\mathrm{a}}$ & $0.035 \pm 0.005^{\mathrm{a}}$ & 0.035 \\
8 & $0.051 \pm 0.001^{\mathrm{a}}$ & $0.049 \pm 0.001^{\mathrm{a}}$ & 0.050 \\
10 & $0.059 \pm 0.009^{\mathrm{a}}$ & $0.046 \pm 0.002^{\mathrm{a}}$ & 0.052 \\
\hline
\end{tabular}

Different letters indicate significant differences (Tukey, $P \leq 0.05$ ).

The coagulant dose is an important coagulation factor since it influences biomass recovery costs. The efficient coagulation-flocculation of the MO was determined based on the removal of microalgal biomass from urban wastewater to produce a clear supernatant. Cultures of S. obliquus in urban wastewater were treated at different flocculant doses: $0.38,0.69,1.23,1.53,1.92$, and $2.61 \mathrm{~g} \mathrm{~L}^{-1}$ (Table 2). The highest flocculation efficiency in algal culture was achieved at an optimum dose of $0.38 \mathrm{~g} \mathrm{~L}^{-1}$, reaching $80.33 \%$ and $72.13 \%$ removal for the treatments with $5 \%$ and $10 \%$ extractive solution $\left(\mathrm{NH}_{4}\right)_{2} \mathrm{SO}_{4}$, respectively (Table 3). The low removal observed for a $10 \%$ saturated solution of $\left(\mathrm{NH}_{4}\right)_{2} \mathrm{SO}_{4}$ could be attributed to the excess of unreacted $\left(\mathrm{NH}_{4}\right)_{2} \mathrm{SO}_{4}$, changing the chemical characteristics of the water, producing a whitish coloration. It is therefore thought that the physical-chemical processes of coagulation-flocculation at the end of the treatment do not contribute surplus reagents that increase the nutrient content, and avoid the possible formation of chloramines in the treated effluents after disinfection.

Table 3. Flocculant dose $\left(\mathrm{g} \mathrm{L}^{-1}\right)$ and final turbidity (\% removal) obtained from the jar test in S. obliquus culture in urban wastewater.

\begin{tabular}{|c|c|c|c|c|}
\hline \multirow{2}{*}{$\frac{\mathrm{g} \text { flocculant }}{\mathrm{mL}\left(\mathrm{NH}_{4}\right)_{2} \mathrm{SO}_{4}}$} & \multirow{2}{*}{ Dose $\left(\mathrm{g} \mathrm{L}^{-1}\right)$} & Turbidity (NTU) & Turbidity (NTU) & $\mathrm{pH}_{\text {Final }}$ \\
\hline & & $\begin{array}{c}\text { Solution Extractor } \\
5 \%\left(\mathrm{NH}_{4}\right)_{2} \mathrm{SO}_{4}\end{array}$ & $\begin{array}{c}\text { Solution Extractor } \\
10 \%\left(\mathrm{NH}_{4}\right)_{2} \mathrm{SO}_{4}\end{array}$ & \\
\hline 0.008 & 0.38 & $12(80.33)$ & 17 (72.13) & 7.05 \\
\hline 0.015 & 0.69 & $20(67.21)$ & $22(63.93)$ & 7.04 \\
\hline 0.024 & 1.23 & $25(59.02)$ & $23(62.30)$ & 7.23 \\
\hline 0.035 & 1.53 & $29(52.46)$ & $23(62.30)$ & 7.12 \\
\hline 0.050 & 1.92 & 49 (19.67) & $24(60.66)$ & 7.90 \\
\hline 0.052 & 2.61 & $24(60.66)$ & $33(45.90)$ & 7.21 \\
\hline
\end{tabular}

Note: NTU: nephelometric turbidity units; Initial turbidity $\left(\mathrm{C}_{0}\right)$ : 61 NTU.

During the treatment of the cultures, increases in dose did not favor the sedimentation of algal biomass (Table 3). Similar results were reported by Abdul-Hamid et al. [6], who found that the efficient recovery of algal biomass Chlorella sp. is possible at a dose of $10 \mathrm{mg} \mathrm{L}^{-1}$, concluding that dose increases result in poor recovery. Ndabigengesere and Narasiah [24] suggested that the addition of coagulant above the optical dose leads to the formation of residual excess coagulant, since all the microalgae particles already form larger colloids.

For urban wastewater, the efficient removal of solids does not differ from the optimal dose obtained in S. obliquus cultures; likewise, increases in coagulant dose does not produce a significant increase in removal efficiency, suggesting that factors such as the concentration of solids and $\mathrm{pH}$ are factors that could affect the aggregation of particles (Table 4). 
Table 4. Flocculant dose $\left(\mathrm{g} \mathrm{L}^{-1}\right)$ and final turbidity (\% removal) obtained from the jar test in urban wastewater.

\begin{tabular}{|c|c|c|c|c|}
\hline \multirow{2}{*}{$\frac{\mathrm{g} \text { flocculant }}{\mathrm{mL}\left(\mathrm{NH}_{4}\right)_{2} \mathrm{SO}_{4}}$} & \multirow{2}{*}{ Dose $\left(\mathrm{g} \mathrm{L}^{-1}\right)$} & Turbidity (NTU) & Turbidity (NTU) & $\mathrm{pH}_{\text {Final }}$ \\
\hline & & $\begin{array}{l}\text { Sol. Extractor } 5 \% \\
\left(\mathrm{NH}_{4}\right)_{2} \mathrm{SO}_{4}\end{array}$ & $\begin{array}{l}\text { Sol. Extractor } 10 \% \\
\left(\mathrm{NH}_{4}\right)_{2} \mathrm{SO}_{4}\end{array}$ & \\
\hline 0.008 & 0.38 & $9.6(98.48)$ & $36(96.33)$ & 6.5 \\
\hline 0.015 & 0.69 & $11.5(98.18)$ & $28(97.15)$ & 6.6 \\
\hline 0.024 & 1.23 & $16.0(97.47)$ & $21(97.86)$ & 6.7 \\
\hline 0.035 & 1.53 & $19.0(97.00)$ & $20(97.96)$ & 6.6 \\
\hline 0.050 & 1.92 & $25.5(95.97)$ & $19(98.06)$ & 6.6 \\
\hline 0.052 & 2.61 & $29.6(95.32)$ & $20(97.96)$ & 6.6 \\
\hline
\end{tabular}

Note: NTU: nephelometric turbidity units.

Beltran-Heredia et al. [25] reported an efficient removal of 50\% in wastewater dyes for a low dose of $25 \mathrm{mg} \mathrm{L}^{-1}$. Similarly, Sanchez-Martin et al. [20] reported a high rate of solids removal from the Meuse River in Rotterdam (The Netherlands) using a low dose of MO coagulant $\left(0.5 \mathrm{mg} \mathrm{L}^{-1}\right)$, suggesting that a low dose is enough to improve the water quality.

Although the dose $\left(0.38 \mathrm{~g} \mathrm{~L}^{-1}\right)$ reported here was higher than those reported in other studies, this dose is low compared to the other treatments, which proved to be efficient in algal cultures and urban wastewater, improving the water's temperature and reducing the one-step coagulant extraction process at a lower cost. Therefore, this dose can be obtained with only $1 \mathrm{~g}$ of $\mathrm{MO}$ (Tables 3 and 4), as can also be observed by comparing the coagulation efficiency using other coagulants (Table 5). This would support its potential application in algal crops for the biomass harvest and production of biodiesel or the extraction of high-value chemicals.

Table 5. Comparative efficiency and dose of flocculants in algal culture media and wastewater.

\begin{tabular}{|c|c|c|c|}
\hline Coagulant-Flocculant & Treatment & $\begin{array}{l}\text { Dose and Efficiency } \\
\text { Removal (\%) }\end{array}$ & Reference \\
\hline Moringa oleifera & $\begin{array}{c}\text { Scenedesmus obliquus } \\
\text { cultivation } \\
\text { Urban wastewater }\end{array}$ & $\begin{array}{c}\text { 72.13-80.33\% } \\
\text { Dose: } 0.38 \mathrm{~g} \mathrm{~L}^{-1} \\
\text { pH: } 7-8\end{array}$ & Our study \\
\hline Chitosan & $\begin{array}{l}\text { Euglema gracilis } \\
\text { cultivation }\end{array}$ & $\begin{array}{c}96-98 \% \\
\text { Dose: } 200 \mathrm{mg} \mathrm{L}^{-1} \\
\text { pH: } 7-7.5\end{array}$ & Gualteri et al. [26] \\
\hline Chitosan & $\begin{array}{l}\text { Rhodomonas báltica } \\
\text { cultivation }\end{array}$ & $\begin{array}{c}75 \% \\
\text { Dose: } 80 \mathrm{mg} \mathrm{L}^{-1}\end{array}$ & Lubian et al. [27] \\
\hline $\begin{array}{l}\text { Acetate } \\
\text { Glucose } \\
\text { Glycerine }\end{array}$ & $\begin{array}{c}\text { Pleurochrysis carterae } \\
\text { cultivation }\end{array}$ & $\begin{array}{l}81-95 \% \\
89-97 \% \\
93-97 \%\end{array}$ & Lee et al. [28] \\
\hline Magnafloc LT25, LT27 & $\begin{array}{c}\text { Chaetoceros calcitrans } \\
\text { cultivation }\end{array}$ & 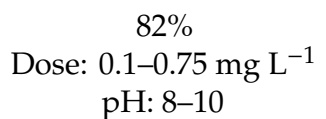 & Harith et al. [29] \\
\hline Chitosan & $\begin{array}{c}\text { Chaetoceros calcitrans } \\
\text { cultivation }\end{array}$ & $\begin{array}{c}83 \% \\
\text { Dose: } 20 \mathrm{mg} \mathrm{L}{ }^{-1} \\
\text { pH: } 5-8\end{array}$ & Harith et al. [29] \\
\hline $\begin{array}{c}\text { Chitosan/aluminum } \\
\text { sulfate }\end{array}$ & Urban Wastewater & $\begin{array}{c}\text { 74.3-98.2\% } \\
\text { Dose: } 0.5-5 \mathrm{mg} \mathrm{L}^{-1} \\
\text { pH: } 7-7.5\end{array}$ & Bina et al. [30] \\
\hline
\end{tabular}

Another variable to study in the coagulation-flocculation process is $\mathrm{pH}$ Experiments with different $\mathrm{pH}$ values were performed in S. obliquus cultures and urban wastewater, varying the $\mathrm{pH}$ between 8 and 13 with a fixed coagulant dose of $0.38 \mathrm{~g} \mathrm{~L}^{-1}$. Tables 6 and 7 show the values of removal (\%) versus $\mathrm{pH}$. The highest efficiencies, $70.97 \%$ and $83.72 \%$, were observed at $\mathrm{pH} 8-9$ with $5 \%$ and $10 \%\left(\mathrm{NH}_{4}\right)_{2} \mathrm{SO}_{4}$ 
solution, respectively. The changes at alkaline $\mathrm{pH}$ release the excess nitrogen in the form of $\mathrm{N}$ gas by shifting the $\mathrm{pH}$ chemical equilibrium to above 9. The tendency of a basic $\mathrm{pH}$ at the end of the treatment would explain the low removal efficiency and turbidity increase in the water by the formation of $\mathrm{SO}_{4}$. In practice, the $\mathrm{pH}$ variation in the wastewater is not significant; it is within the values of 8 and 9, so $\mathrm{pH}$ adjustments are not necessary for the removal of solids. According to Beltran-Heredia et al. [25], the effective $\mathrm{pH}$ for coagulation is in the range of 7 to 9 , similar to the present study. This result was similar to that reported in other studies where coagulation-flocculation processes are $\mathrm{pH}$-dependent, such as wastewater with high metal contents [31,32].

Table 6. Determining the optimal $\mathrm{pH}$ and final turbidity (\% removal) obtained from the jar test in the microalgal culture at an optimum flocculant dose of $0.38 \mathrm{~g} \mathrm{~L}^{-1}$.

\begin{tabular}{cccc}
\hline \multirow{2}{*}{$\mathbf{p H}$} & \begin{tabular}{c} 
Turbidity (NTU) \\
\cline { 2 - 4 }
\end{tabular} & $\begin{array}{c}\text { Turbidity (NTU) } \\
\mathbf{( N H}_{\mathbf{4}} \mathbf{~} \mathbf{2}_{\mathbf{2}} \mathbf{S O}_{\mathbf{4}}\end{array}$ & $\begin{array}{c}\mathbf{p H}_{\text {final }} \\
\text { Sol. Extractor } \mathbf{1 0} \% \\
\mathbf{( N H}_{\mathbf{4}} \mathbf{~} \mathbf{2}_{\mathbf{2}} \mathbf{S O}_{\mathbf{4}}\end{array}$ \\
\hline 8 & $5.7(70.97)$ & $8.8(55.10)$ & 7.25 \\
9 & $3.2(83.72)$ & $7.5(61.58)$ & 7.66 \\
10 & $2.6(86.58)$ & $5.8(70.56)$ & 8.23 \\
11 & $2.7(86.07)$ & $5.7(70.66)$ & 8.48 \\
12 & $2.3(88.27)$ & $3.6(81.63)$ & 9.37 \\
13 & $3.6(81.68)$ & $1.1(94.39)$ & 12.76 \\
\hline
\end{tabular}

Table 7. Determining the optimal $\mathrm{pH}$ and final turbidity (\% removal) obtained from the jar test in urban wastewater at an optimum flocculant dose of $0.38 \mathrm{~g} \mathrm{~L}^{-1}$.

\begin{tabular}{|c|c|c|c|}
\hline \multirow{2}{*}{$\mathrm{pH}$} & Turbidity (NTU) & Turbidity (NTU) & $\mathrm{pH}_{\text {final }}$ \\
\hline & $\begin{array}{l}\text { Sol. Extractor } 5 \% \\
\left(\mathrm{NH}_{4}\right)_{2} \mathrm{SO}_{4}\end{array}$ & $\begin{array}{l}\text { Sol. Extractor } 10 \% \\
\left(\mathrm{NH}_{4}\right)_{2} \mathrm{SO}_{4}\end{array}$ & \\
\hline 8 & $4.9(99.41)$ & $16.0(98.0)$ & 8.1 \\
\hline 9 & $3.1(99.63)$ & $15.0(98.13)$ & 9.2 \\
\hline 10 & $4.2(99.49)$ & $18.0(97.75)$ & 9.5 \\
\hline 11 & $4.3(99.49)$ & $9.0(98.88)$ & 10.3 \\
\hline 12 & $3.6(99.57)$ & $7.0(99.13)$ & 12.3 \\
\hline 13 & $3.4(99.59)$ & $2.0(99.75)$ & 13.1 \\
\hline
\end{tabular}

At the end of the treatment period, the quality of the residual water in the S. obliquus cultures and only the residual waters (control), there were reductions in total solids (TDS) and biochemical oxygen demand (BOD) of approximately 95\%. These concentrations are lower than those established by Mexican regulations (NOM-001-SEMARNAT, 1996); the maximum permissible limits for the control of wastewater discharge in estuaries and wetlands for SDT and BOD are 25 and $150 \mathrm{mg} \mathrm{L}^{-1}$, respectively.

\section{Methyl Esters Fatty Acids Profile (FAME)}

The fatty acids profile for Moringa oleifera, in comparison to that obtained from biomass harvested from S. obliquus after flocculation, did not show significant differences $(P=0.996)$. This suggests that both oils have similar characteristics, with an SFA content of 36.24-36.54\%, monounsaturated fatty acid (MUFA) content of 32.78-36.13\%, and a polyunsaturated fatty acid (PUFA) content of $27.63-30.67 \%$ (Table 8). In particular, the activity of the flocculant on the quality properties of the oil obtained by S. obliquus could be observed as not having a significant effect for the synthesis of biodiesel (Table 9). 
Table 8. Methyl Esters Fatty Acids Profile (FAME) (\% w/w) of Moringa oleifera and microalgae S. obliquus harvested after flocculation.

\begin{tabular}{|c|c|c|}
\hline FAME & Moringa oleifera & Scenedesmus obliquus \\
\hline Butyric acid (C4: 0) & 2.97 & 1.21 \\
\hline Caproic acid (C6: 0) & 0.42 & 1.54 \\
\hline Caprylic acid (C8: 0$)$ ) & 0.61 & 1.26 \\
\hline Capric acid (C10: 0$)$ & 1.42 & 0.90 \\
\hline Undecanoic acid (C11: 0) & 0.84 & 2.02 \\
\hline Lauric acid (C12: 0) & 2.95 & 1.25 \\
\hline Tridecanoic acid (C13: 0) & 2.14 & 0.92 \\
\hline Acid Miristic (C14: 0) & 2.78 & 2.54 \\
\hline Pentadecanoic Acid (C15: 0) & 2.37 & 3.93 \\
\hline Palmitic Acid (C16: 0) & 3.16 & 2.25 \\
\hline Heptadecainoic Acid (C17: 0) & 3.27 & 3.28 \\
\hline Stearic Acid (C18: 0) & 3.33 & 2.16 \\
\hline Arachidic Acid (C20: 0) & 1.32 & 1.39 \\
\hline Heneicosanoic acid (C21: 0) & 3.42 & 3.86 \\
\hline Behenic acid (C22: 0) & 2.53 & 3.88 \\
\hline Tricosanoic acid (C23: 0) & 2.68 & 2.70 \\
\hline Lignoceric acid (C24: 0) & 0 & 1.38 \\
\hline Miristoleic acid (C14: 1) & 3.09 & 1.16 \\
\hline Cis-pentadecanoic acid (C15: 1) & 3.15 & 1.19 \\
\hline Palmitoleic acid (C16: 1)) & 1.71 & 0.76 \\
\hline Cis-Heptadecainoic acid (C17: 1) & 2.26 & 6.93 \\
\hline Elaidic acid (C18: 1N9T) & 4.05 & 8.61 \\
\hline Oleic acid (C18: 1N9C) & 4.79 & 3.18 \\
\hline Gadoleic acid (C20: 1) & 2.34 & 1.15 \\
\hline Erucic acid (C22: 1N9) & 6.05 & 1.38 \\
\hline Nervonic acid (C24: 1) & 8.67 & 8.38 \\
\hline Linoleic acid (C18: 2N6T) & 2.57 & 1.54 \\
\hline Linoelaidic acid (C18: 2N6C) & 1.52 & 2.71 \\
\hline Linolenic acid (C18: 3N6) & 6.21 & 3.49 \\
\hline$\alpha$-Linolenic acid (C18: 3N3) & 0.18 & 0.58 \\
\hline Eicosadienoic acid (C20: 2) & 1.34 & 2.96 \\
\hline Dihomo- - -Linolenic acid (C20: 3N6) & 1.23 & 1.92 \\
\hline Eicosatrienoic acid (C20: 3N3) & 0 & 0.92 \\
\hline Arachidonic Acid (C20: 4N6) & 3.34 & 1.05 \\
\hline Docosaadienic Acid (C22: 2) & 1.78 & 3.96 \\
\hline Eicosapentaenoic Acid (C20: 5N3) & 3.16 & 5.54 \\
\hline Docosahexaenoic Acid (C22: 6N3) & 6.28 & 5.97 \\
\hline SAF (\% wt) & 36.24 & 36.54 \\
\hline MUFA (\% wt) & 36.13 & 32.78 \\
\hline PUFA (\% wt) & 27.63 & 30.67 \\
\hline LCSF (\% wt) & 5.91 & 10.05 \\
\hline SFA/PUFA & 1.3 & 1.2 \\
\hline
\end{tabular}

SFA: saturated fatty acid, MUFA: monounsaturated fatty acid, PUFA: polyunsaturated fatty acid, LCSF: long chain saturation factor. Values are average of triplicates.

The SFA, MUFA, and PUFA contents affect the quality of biodiesel. An oil containing high concentrations of PUFA and MUFA compared with SFAs tends to produce biodiesel with a high iodine value and poor oxidative stability. However, this was not observed for the S. obliquus cultivated in domestic wastewater and Moringa oleifera seed (Table 8). Therefore, the quality parameters evaluated using the CN and SV were related to the saturation of FAME in both M. oleifera and S. obliquus.

The CN was low compared with the value recommended by international standards ASTM 6751 and EN14214 (Table 9) for both microalgae and M. oleifera. Our studies suggest that high cetane number and proportions of SFA could be associated with efficient combustion properties of biodiesel, similar to those reported by other authors [33,34]. Wu and Miao [28] reported a CN for S. obliquus positively 
correlated with the SFA content and negatively correlated with DU, suggesting good ignition of the fuel when the SFA/PUFA ratio is approximately 2.31-4.02. For S. obliquus and M. oleifera, the SFA/PUFA ratios were low at 1.2-1.3 (Table 8), indicating good ignition of biodiesel. The SFA amount with respect to the PUFA amount may provide the best indication of the good ignition of a biodiesel; conversely, a high percentage of SFA affects the flow properties, causing the crystallization and solidification of the fuel in engine filters under colder climatic conditions [35]. An analysis of the biodiesel produced by S. obliquus where the SFAs and MUFAs dominate suggest poor cold flow properties; therefore, the use of this biodiesel in cold climate conditions may be limited. This problem could be minimized by mixing with oil from other species with opposite characteristics [23]. For M. oleifera, we propose its use as a biodiesel in practical applications in warm climates.

The iodine value (IV) is related to the oxidative stability, implying that biodiesel with high IV values are less stable to oxidation [36]. In the present study, the biodiesel obtained by S. obliquus and M. oleifera showed IV values close to $120 \mathrm{~g} \mathrm{I}_{2} 100 \mathrm{~g}^{-1}$ lipids, and an oxidative stability (OS) value within three to six minutes according to the values established by the European standard (Table 8). The IV, DU, CFPP, and OS values in comparison with other studies for S. obliquus are similar, within the range established by ASTM D6751 and EN 14,214 standards (Table 9) [21-23,33,37,38], suggesting that the biodiesel obtained from the harvested S. obliquus using M. oleifera bioflocculants has good oxidative stability. This also suggests that the bioflocculant did not negatively affect the biodiesel quality. In accordance with other studies (Table 9) $[21-23,33,37,38]$, we conclude that oil rich in SFA will generate biodiesel with high $\mathrm{CN}$, low IV, and high oxidative stability, whereas oils with high PUFA content (high DU) will produce biodiesel with low CN and high IV, and will be more prone to oxidation.

Table 9. The physico-chemical properties of Scenedesmus obliquus base biodiesel production compared with international standards and those in other studies.

\begin{tabular}{|c|c|c|c|c|c|c|c|c|c|c|c|}
\hline $\begin{array}{l}\text { Biodiesel } \\
\text { Properties }\end{array}$ & Units & $\begin{array}{l}\text { ASTM } \\
\text { D6751 }\end{array}$ & $\begin{array}{c}\text { EN } \\
14214\end{array}$ & [37] & [33] & [21] & [23] & [22] & [38] & S. obliquus & M. oleifera \\
\hline $\mathrm{CN}$ & $\min$ & 47 & 51 & 59.98 & 57.93 & 57.13 & 63.63 & 51.74 & 40.2 & 45.75 & 45.43 \\
\hline IV & $\mathrm{g} \mathrm{I}_{2} 100 \mathrm{~g}^{-1}$ & - & 120 & 77.36 & 72.81 & 77.91 & 35.38 & 98.86 & 27.2 & 119.64 & 117.52 \\
\hline CFPP & ${ }^{\circ} \mathrm{C}$ & - & $\leq 5 \leq-20$ & -3.19 & -5.68 & -0.04 & -11.87 & 3.5 & -7.1 & 2.08 & 15.09 \\
\hline SV & $\begin{array}{c}\mathrm{mg} \mathrm{KOH} \\
\mathrm{g}^{-1}\end{array}$ & - & - & 164.6 & 194.8 & 192.4 & 216.0 & - & 315.3 & 206.95 & 213.44 \\
\hline DU & $\% \mathrm{wt}$ & - & - & 87.04 & 83.97 & - & 36.63 & - & 30.83 & 94.13 & 91.38 \\
\hline OS & $\mathrm{h}$ & 3 & 6 & 7.31 & - & - & - & 3.53 & 6.6 & 4.15 & 4.26 \\
\hline
\end{tabular}

CN: cetane number; IV: iodine value; CFPP: cold filter plugging point; SV: saponification value; DU: degree of unsaturation; OS: oxidative stability; SFA: saturated fatty acid; MUFA: monounsaturated fatty acid; PUFA: polyunsaturated fatty acid. Values are average of triplicates.

\section{Conclusions}

The growing demand for chemical coagulants for wastewater treatment has led to the search for new sources of cost-effective organizer coagulants to reduce the impacts of wastewater on ecosystems. The Moringa oleifera seed shows potential as a low cost coagulant-flocculant that could be used in harvesting the microalgae that grows in urban wastewater, in addition to improving the quality of the effluents emitted from treatment plants. In the present study, the extraction of flocculant with $5 \%\left(\mathrm{NH}_{4}\right)_{2} \mathrm{SO}_{4}$ solution without purification achieved $80.33 \%$ removal with a low dose of $0.38 \mathrm{~g} \mathrm{~L}^{-1}$. Enough flocculant ( $0.47 \mathrm{~g}$ flocculant) was obtained from $1 \mathrm{~g}$ of $M$. oleifera. The extracting solution of $\left(\mathrm{NH}_{4}\right)_{2} \mathrm{SO}_{4}$ at $10 \%$ produces excess nitrogen that is released in the form of $\mathrm{N}$ gas at basic $\mathrm{pH}$ values (above 9), producing whitish turbidity.

The oil profile (MO and S. obliquus) showed contents of saturated fatty acids (SFA) of 36.24-36.54\%, monounsaturated fatty acids of $32.78-36.13 \%$, and polyunsaturated fatty acids of $27.63-30.67 \%$. The biodiesel produced by S. obliquus and harvested from urban wastewater showed that when the SFAs dominate the MUFAs, the biodiesel has poor cold flow properties. Therefore, this application of 
this biodiesel in cold climates may be limited, although this problem can be minimized by mixing it with oil from other species with opposite characteristics. M. oleifera is proposed for use as a biodiesel in warm climates. For both oils, the high cetane number $(\mathrm{CN})$ is positively correlated with high SFA content and negatively correlated with the degree of saturation (DU), suggesting good fuel ignition and good oxidative stability properties, likewise suggesting that the bioflocculant negatively affects the biodiesel's quality. This makes MO a potentially harmless bioflocculant for microalgal harvesting in urban wastewater, contributing to the treatment of wastewater and providing a possible source of low-cost biodiesel.

Author Contributions: A.R.-M., Y.C.-L., M.L.S.-C. contributed to this manuscript from conceptualization, methodology, research, writing-original draft preparation, to writing-review; A.N.-G. contributed to this manuscript from methodology and laboratory analysis (extraction and identification of fatty acids; J.d.C.Z.-L., L.A.D.-L. contributed to this manuscript from methodology and quality analysis of biodiesel; J.C.-Á., E.G.-V., P.A.-T. contributed to this manuscript from research, writing — original draft preparation, to writing-review.

Funding: This research received no external funding.

Acknowledgments: We acknowledgement the members of the CAEC in Environmental Engineering and Universidad Autónoma del Carmen (UNACAR) and Department of the Doctorate in Industrial Engineering Universidad Internacional Iberoamericana A.C for their encouragement and support.

Conflicts of Interest: The authors declare that they have no conflict of interest, financial or otherwise.

\section{References}

1. Regine, H.S.F.; Volesky, B. Biosorption a solution to pollution. Int. Microbiol. 2000, 3, 17-24.

2. Kituyi, J.L.; Foulkes, M.; Worsfold, P.; Ongulu, R.A.; Kiplagat, A.; Gachanja, A. Efficiency of pre-treated Moringa oleifera for the removal of $\mathrm{Cd}^{2+}$ and $\mathrm{Zn}^{2+}$ ions from wastewaters. Ecohydrol. Hydrobiol. 2013, 13, 267-271. [CrossRef]

3. Brennan, L.; Owende, P. Biofuels from microalgae- A review of technologies for production, processing, and extractions of biofuels and Co-Products. Renew. Sustain. Energy Rev. 2010, 14, 557-577. [CrossRef]

4. Ruiz-Marín, A.; Mendoza-Espinosa, L.G.; Stephenson, T. Growth and nutrient removal in free and immobilized green algae in batch and semicontinuous cultures treating real wastewater. Bioresour. Technol. 2010, 101, 58-64. [CrossRef] [PubMed]

5. Chen, C.Y.; Yeh, K.L.; Aisyah, R.; Lee, D.J.; Chang, J.S. Cultivation, photobioreactor desing and harvesting of microalgae for biodiesel production: A critical review. Bioresour. Technol. 2011, 102, 71-81. [CrossRef] [PubMed]

6. Abdul-Hamid, S.H.; Lananan, F.; Sakinah-Din, W.N.; Lam, S.S.; Khatoon, H.; Endut, A.; Jusoh, A. Harvesting microalgae, Chlorella sp. by Bio-Flocculation of Moringa oleifera seed derivatives from aquaculture wastewater phytoremediation. Int. Biodeterior. Biodegrad. 2014, 95, 270-275. [CrossRef]

7. Lananan, F.; Jusoh, A.; Ali, N.; Lam, S.S.; Endut, A. Effect of Conway Medium and f/2 Medium on the growth of six genera of South China Sea marine microalgae. Bioresour. Technol. 2013, 141, 75-82. [CrossRef]

8. Zhu, H.Y.; Jiang, R.; Xiao, L.Y.; Chang, Y.H.; Guan, Y.J.; Li, X.D.; Zeng, G.M. Photocatalytic decolorization and degradation of Congo network on innovative crosslinked chitosan/nano-CdS composite catalyst under visible light irradiation. J. Hazard. Mater. 2009, 169, 933-940. [CrossRef]

9. Zheng, Y.P.; Yao, G.H.; Cheng, Q.B.; Yu, S.C.; Liu, M.D.; Gao, C.J. Positively charged Thin-Film composite hollow fiber nanofiltration membrane for the removal of cationic dyes through submerged filtration. Desalination 2013, 328, 42-50. [CrossRef]

10. Tie, J.; Jiang, M.; Li, H.; Zhang, S.; Zhang, X. A comparison between Moringa oleifera seed presscake extract and polyaluminum chloride in the removal of direct black 19 from synthetic wastewater. Ind. Crop. Prod. 2015, 74, 530-534. [CrossRef]

11. Huang, X.; Bo, X.W.; Zhao, Y.X.; Gao, B.Y.Y.; Wang, Y.; Sun, S.L.; Yue, Q.Y.; Li, Q. Effects of compound bioflocculant on coagulation performance and floc properties for dye removal. Bioresour. Technol. 2014, 165, 116-121. [CrossRef] [PubMed] 
12. Spencer, P.S.; Schaumburg, H.H. Nervous system degeneration produced by acrylamide monomer. Environ. Health Perspect. 1975, 11, 129-133. [CrossRef] [PubMed]

13. Bhatia, S.; Othman, Z.; Ahmad, A.L. Coagulation-Flocculation process for POME treatment using Moringa oleifera seeds extract: Optimization studies. Chem. Eng. J. 2007, 133, 205-212. [CrossRef]

14. Ahmad, A.L.; Mat Yasin, N.H.; Derek, C.J.C.; Lim, J.K. Optimization of microalgae coagulation process using chitosan. Chem. Eng. J. 2011, 173, 879-882. [CrossRef]

15. Pritcharda, M.; Craven, T.; Mkandawire, T.; Edmondson, A.S.; O'Neill, J.G. A comparison between Moringa oleifera and chemical coagulants in the purification of drinking water-An alternative sustainable solution for developing countries. Phys. Chem. Earth 2010, 35, 798-805. [CrossRef]

16. Teixeira, C.M.L.L.; Kirsten, F.V.; Teixeira, P.C.N. Evaluation of Moringa oleifera seed flour as a flocculating agent for potential biodiesel producer microalgae. J. Appl. Phycol. 2012, 24, 557-563. [CrossRef]

17. Sato, N.; Murata, N. Membrane lipids. In Methods in Enzymology; Colowick, S.P., Kaplan, N.O., Eds.; Academic Press: Cambridge, UK, 1988; pp. 251-259.

18. Canedo-López, Y.; Ruiz-Marín, A.; Zavala-Loría, J.C. A Two-Stage culture process using Chlorella vulgaris for urban wastewater nutrient removal and enhanced algal lipid accumulation under photoautotrophic and mixotrophic conditions. J. Renew. Sustain. Energy 2016, 8, 033102. [CrossRef]

19. Guillard, R.L.L.; Ryther, J.H. Studies on marine planktonic diatoms Cyclotella nana Hustedt and Detonula confervacea (Cleve) Gran. Can. J. Microbiol. 1962, 8, 229-239. [CrossRef]

20. Sánchez-Martín, J.; Ghebremichael, K.; Beltrán-Heredia, J. Comparison of Single-Step and Two-Step purified coagulants from Moringa oleifera seed for turbidity and DOC removal. Bioresour. Technol. 2010, 101, 6259-6261. [CrossRef]

21. Vidyashankar, S.; VenuGopal, K.S.; Kavitha, M.D. Characterization of fatty acids and hydrocarbons of chlorophycean microalgae towards their use as biofuel source. Biomass Bioenergy 2015, 77, 75-91. [CrossRef]

22. Guldhe, A.; Singh, P.; Kumari, S.; Rawat, I.; Permaul, K.; Bux, F. Biodiesel synthesis from microalgae using immobilized Aspergillus niger whole cell lipase biocatalyst. Renew. Energy 2016, 85, 1002-1010. [CrossRef]

23. Nascimento, I.A.; Izabel-Marques, S.S.; Dominguez-Cabanelas, I.T. Screening microalgae strains for biodiesel production: Lipid productivity an estimation of fuel quality base on fatty acids profiles as selective criteria. Bioenergy Res. 2013, 6, 1-13. [CrossRef]

24. Ndabigengesere, A.; Narasiah, K.S. Quality of water treated by coagulation using Moringa oleifera seeds. Water Res. 1998, 32, 781-791. [CrossRef]

25. Beltrán-Heredia, J.; Sánchez-Martín, J.; Muñoz-Serrano, A.; Peres, J.A. Towards overcoming TOC increase in wastewater treated with Moringa oleifera seed extract. Chem. Eng. J. 2012, 188, 40-46. [CrossRef]

26. Gualteri, P.; Barsanti, L.; Passarelli, V. Harvesting Euglena gracilis cells with a nontoxic flocculant. J. Microbiol. Methods 1988, 8, 327-332. [CrossRef]

27. Lubian, L.M. Concentrating cultured marine microalgae with chitosan. Aquac. Eng. 1989, 8, $257-265$. [CrossRef]

28. Lee, A.K.; Lewis, D.M.; Ashman, P.J. Microbial flocculation, a potentially Low-Cost harvesting technique for marine microalgae for the production of biodiesel. J. Appl. Phycol. 2009, 21, 559-567. [CrossRef]

29. Harith, Z.T.; Ariff, A.B.; Yusoff, F.M.; Mohamed, M.S.; Shariff, M.; Din, M. Effect of different flocculants on the flocculation performance of microalgae, Chaetoceros calcitrans, cells. Afr. J. Biotechnol. 2009, 8, 5971-5978.

30. Bina, B.M.H.; Mehdinejad, M.; Nikaeen, H.; Attar, H.M. Effectiveness of chitosan as natural coagulant aid in treating turbid waters. Iran. J. Environ. Health Sci. Eng. 2009, 6, 247-252.

31. Sánchez-Martín, J.; González-Velasco, M.; Beltrán-Heredia, J. Acacia mearnsii from wild Tannin-Based flocculant in surface water treatment. J. Wood Chem. Technol. 2009, 29, 119-135. [CrossRef]

32. Tan, B.H.; Teng, T.T.; Omar, A.K.M. Removal of dyes and industrial dye wastes by magnesium chloride. Water Res. 2000, 34, 597-601. [CrossRef]

33. Wu, H.; Miao, X. Biodiesel quality and biochemical changes of microalgae Chlorella pyrenoidosa and Scenedesmus obliquus in response to nitrate levels. Bioresour. Technol. 2014, 170, 421-427. [CrossRef] [PubMed]

34. Mujtaba, G.; Choi, W.; Lee, C.G.; Lee, K. Lipid production by Chlorella vulgaris after a shift from nutrient-Rich to nitrogen starvation conditions. Bioresour. Technol. 2012, 123, 279-283. [CrossRef] [PubMed] 
35. Rinna, F.; Buono, S.; Dominguez, C.I.T.; Nascimento, A.I.; Sansone, G.; Assunta-Barone, C.M. Wastewater treatment by microalgae can generate high quality biodiesel feedstock. J. Water Proc. Eng. 2017, 18, 144-149. [CrossRef]

36. Knothe, G. Improving biodiesel fuel properties by modifying fatty ester composition. Energy Environ. Sci. 2009, 2, 759-766. [CrossRef]

37. Arora, N.; Pate, 1.A.; Pruthi, P.A.; Pruthi, V. Boosting TAG accumulation with improved biodiesel production from novel oleaginous microalgae Scenedesmus sp. IITRIND2 utilizing waste Sugarcane Bagasse Aqueous Extract (SBAE). Appl. Biochem. Biotechnol. 2016, 180, 109-121. [CrossRef] [PubMed]

38. Ruiz-Marin, A.; Canedo-López, Y.; Narvaez-García, A.; Robles-Heredia, J.C.; Zavala-Loria, J.C. Productivity and Biodiesel Quality of Fatty Acids Contents from Scenedesmus obliquus in Domestic Wastewater Using Phototrophic and Mixotrophic Cultivation Systems. Open Biotechnol. J. 2018, 12, 229-240. [CrossRef]

C 2019 by the authors. Licensee MDPI, Basel, Switzerland. This article is an open access article distributed under the terms and conditions of the Creative Commons Attribution (CC BY) license (http://creativecommons.org/licenses/by/4.0/). 